\title{
Low-cost struvite production using source-separated urine in Nepal
}

\author{
B. Etter, E. Tilley, R. Khadka, K.M. Udert
}

Eawag: Swiss Federal Institute of Aquatic Science and Technology, Überlandstrasse 133, 8600 Dübendorf, Switzerland bastian.etter@eawag.ch

elizabeth.tilley@eawag.ch

raju.khadka@eawag.ch

Corresponding author: kai.udert@eawag.ch, phone: +414482353 60, fax: +41448235389

\begin{abstract}
This research investigated the possibility of transferring phosphorus from human urine into a concentrated form that can be used as fertilizer in agriculture. The community of Siddhipur in Nepal was chosen as a research site, because there is a strong presence and acceptance of the urine-diverting dry toilets needed to collect urine separately at the source. Furthermore, because the mainly agricultural country is landlocked and depends on expensive, imported fertilizers, the need for nutrient security is high. We found that struvite $\left(\mathrm{MgNH}_{4} \mathrm{PO}_{4} \cdot 6 \mathrm{H}_{2} \mathrm{O}\right)$ precipitation from urine is an efficient and simple approach to produce a granulated phosphorus fertilizer. Bittern, a waste stream from salt production, is a practical magnesium source for struvite production, but it has to be imported from India. Calculations show that magnesium oxide produced from locally available magnesite would be a cheaper magnesium source. A reactor with an external filtration system was capable of removing over $90 \%$ of phosphorus with a low magnesium dosage $\left(1.1 \mathrm{~mol}\right.$ Mg.mol $\left.\mathrm{P}^{-1}\right)$, with coarse nylon filters (pore width up to $160 \pm 50 \mu \mathrm{m}$ ) and with only one hour total treatment time. A second reactor setup based on sedimentation only achieved $50 \%$ phosphate removal, even when flocculants were added. Given the current fertilizer prices, high volumes of urine must be processed, if struvite recovery should be financially sustainable. Therefore, it is important to optimize the process. Our calculations showed that collecting the struvite and calcium phosphate precipitated spontaneously due to urea hydrolysis could increase the overall phosphate recovery by at least $40 \%$. The magnesium dosage can be optimized by estimating the phosphate concentration by measuring electrical conductivity. An important source of additional revenue could be the effluent of the struvite reactor. Further research should be aimed at finding methods and technologies to recover the nutrients from the effluent.
\end{abstract}

\section{KEYWORDS}

magnesium ammonium phosphate (MAP); nutrient recovery; phosphorus; sustainable sanitation; struvite precipitation; urine separation;

\section{INTRODUCTION}

Extensive sewer networks with large centralized wastewater treatment plants have been the common civil engineering approach to provide sanitation in urban and peri-urban areas. However, the high investment and operating costs, dependency on increasingly scarce resources (e.g. water and fossil fuels), and intensive maintenance make this system not only unattainable, but unsustainable for most areas in the developing world. To reverse the trend of reproducing inappropriate designs, there is a growing demand for new technologies, which better suit the needs of the local population and their environment (Larsen et al., 2009; Guest et al., 2009, Tilley et al., 2008a) and which emphasize the value of wastewater as a resource from which nutrients, water or energy can be recovered.

The goal of extracting value from waste is to maximize the social, environmental and health benefits while minimizing the investment and operation costs (Schuen et al., 2009). Recovering resources from wastewater might allow the free market to play a role in the sanitation in developing countries by supporting small businesses that collect the waste, treat it and sell the value-added products.

The present study focuses on the recovery of phosphorus from urine. Worldwide, approximately 50 to $60 \%$ of the phosphorus fertilizer demand is covered by mineral fertilizer (Smil, 2000). However, mineral phosphorus, like oil, is a finite resource and supplies are expected to peak around 2030 (Cordell et al., 2009). To prevent food shortages, additional phosphorus sources must be exploited, such as human and animal excreta (ibid.). In fact, humans typically excrete 1.6 to $1.7 \mathrm{~g}$ phosphorus per day, most of which (about $60 \%$ ) is found in urine (Schouw et al., 2002). Alternative sanitation concepts, which are based on the separation and collection of excreta at the source, facilitate the recycling of nutrients from faeces and urine to agriculture (Larsen et al., 2009; Jönsson et al., 2004).

However, preliminary treatment of urine is needed to prevent nutrient loss by ammonia volatilization, to reduce weight (caused by the water content of urine) and to remove pathogens. Composting is a common and effective treatment for faeces (Niwagaba et al., 2009) and several treatment methods have been proposed for urine (Maurer et al., 2006), but few have been tested as thoroughly as struvite precipitation (see Ronteltap et al., 2010 and Tilley et al., 2008b for an overview). Through a basic precipitation reaction, the majority of phosphorus in urine can be crystallized into a white, odourless powder called struvite or magnesium ammonium phosphate hexahydrate (MAP, $\mathrm{MgNH}_{4} \mathrm{PO}_{4} \cdot 6 \mathrm{H}_{2} \mathrm{O}$ ). Struvite is an effective phosphorus fertilizer (Johnston and Richards, 2004; Römer, 2006), it is compact and can be stored and transported easily.

Full-scale struvite reactors have been used for several years to recover phosphate from different solutions such as WWTP digester supernatant, swine manure or agro-industry wastewater (Forrest et al. 2008; Bowers et al., 2005; Moerman et al. 2009). However, these reactors are too large and too complex for urine treatment on a small scale in developing countries. Recently, a stainless steel reactor has been manufactured commercially 
to produce struvite from urine in decentralized settings (Paris et al. 2007; Abegglen, 2008; Antonini et al., 2009). The reactor is equipped with a spiral pump (precipitant dosage), magnetic valves and a process unit to allow for automated operation. Antonini et al. (2009) reported that they used magnesium oxide as the precipitant and dosed it at a molar ratio of $1.5 \mathrm{~mol} \mathrm{Mg} \cdot \mathrm{mol} \mathrm{P}^{-1}$. After the magnesium dose, the mixture was stirred for 30 minutes and then left to settle for 3 hours. The precipitate was later collected in a filter bag attached to the outflow of the reactor. The phosphate removal was as high as $98 \%$. Abegglen (2008) dosed magnesium at a molar ratio of $1.8 \mathrm{~mol} \mathrm{Mg} \cdot \mathrm{mol} \mathrm{P}^{-1}$ and observed phosphate removal efficiencies higher than 95\%. The reactor type used in the studies by Abegglen (2008) and Antonini et al. (2009) has proven to be very suitable for pilot studies with a reliable power supply, but the investment costs are still rather high. In our project, we wanted to build struvite reactors, which conform to the requirements of low-cost sanitation systems in Nepal, i.e. where the struvite process uses only locally available inputs, without in-depth technical knowledge, and without continuous electricity supply.

Siddhipur, a village close to Kathmandu, was chosen as the project site. The opportunity and need to implement alternative sanitation in Nepal is large, as only $27 \%$ of the population has access to improved sanitation, (of which, $3 \%$ are connected to sewers) (WHO/UNICEF, 2010). Although urine diverting dry toilets (UDDT) have been promoted heavily in recent years, the use of urine directly as a fertilizer is not common in Nepal (WaterAid, 2007).

We conducted a comprehensive study to assess the technical and economic feasibility of producing struvite from source-separated urine in Nepal. Specifically, the determination of phosphate content in the influent (urine), the economics of magnesium sources for the precipitation process, the most efficient technology for crystal recovery, the potential of flocculants to improve phosphate recovery, the role of the filter cake on the recovery of struvite, and the production of a user-friendly granulated struvite fertilizer, were investigated. This study emphasized the technology's reproducibility by making maximum use of locally available resources.

\section{MATERIALS AND METHODS}

\subsection{Location and Community}

The village of Siddhipur was chosen as pilot test site because of the high number of operating UDDTs (100+) (Water Aid, 2007), the institutional strength of the Drinking Water and Sanitation User Committee, and the well-established contacts to development agencies. The majority of Siddhipur's population engages in agriculture and the predominant ethic group in the settlement (Newar) has traditionally used human and animal excreta as fertilizers (Water Aid, 2007).

\subsection{Urine sources, quantity and quality}

A bicycle, modified with a steel rack to carry two $20 \mathrm{~L}$ plastic jerry cans, was used to collect the urine from a dozen households, where the urine had been stored in $100 \mathrm{~L}$ tanks connected to the UDDTs. Due to the occasional cleaning of the UDDTs with water, the urine was slightly diluted. Approximately $250 \mathrm{~L}$ of urine were collected during one day. This quantity was sufficient for one week of experiments. Fresh urine samples from 14 individuals ( 8 male, 6 female, aged between 6 and 64) were collected to determine typical nutrient concentrations before storage.

\subsection{Analytical methods}

Prior to analysis, urine samples were filtered with membrane filters (Whatman, Maidstone, UK) to a final pore size of $0.45 \mu \mathrm{m}$. The phosphate concentration in the stored urine samples was measured using a portable Hach DR 2000 photo-spectrometer (molybdovanadate method, Hach, Denver (CO), USA). To determine total phosphate, phosphate mineral particles were dissolved by adding $1 \mathrm{M}$ hydrochloric acid. Electrical conductivity and $\mathrm{pH}$ values were measured with a portable conductivity meter (LF 340, WTW, Weilheim, Germany) and a portable $\mathrm{pH}$ meter ( $\mathrm{pH} 330$, WTW, Weilheim, Germany), respectively. The temperature effect was compensated for $25{ }^{\circ} \mathrm{C}$ by a linear function of $1.91 \% \cdot \mathrm{K}^{-1}$ (Standard Methods, 2006). Chloride, sulfate and phosphate (only fresh urine) were analyzed with ion chromatography (IC, Metrohm, Herisau, Switzerland), while cations (potassium, sodium and magnesium) were determined with inductively coupled plasma optical emission spectrometry (ICP-OES, Ciros, Spectro Analytical Instruments, Kleve, Germany). Ammonium was measured photometrically on a flow injection analyzer (Application Note 5520, FOSS, Hillerød, Denmark). Urea was calculated as the difference between ammonia after digestion with urease and the initial ammonia in the sample (Eawag standard operation procedure). Chemical oxygen demand (COD) was measured with Dr. Lange cuvet tests (LCK 614, Lange, Berlin, Germany). Magnesium sulphate was powdered and dissolved in distilled water prior to analysis. The magnesite samples were dissolved using aqua regia digestion and microwaved before analyzing the magnesium content with ICP-OES. The pore size of the filter bag was characterized by the maximum pore width (average of thirty measurements) measured under a light microscope.

\subsection{Magnesium sources}

Three different types of magnesium sources were investigated to determine the most cost effective and chemically appropriate precipitant for struvite production in Siddhipur: magnesium sulphate, bittern and magnesite rock from Nepal. Magnesium sulphate heptahydrate granulate $\left(\mathrm{MgSO}_{4} \cdot 7 \mathrm{H}_{2} \mathrm{O}\right.$, Rohit Chemicals, Birganj imported to Nepal from India) was bought on the fertilizer market. Bittern, the waste brine remaining after salt $(\mathrm{NaCl})$ extraction from seawater, was directly obtained from the Jakhau Salt Company in Gujarat, India. Bittern was used as a magnesium source in all our field and lab experiments. Magnesite $\left(\mathrm{MgCO}_{3}\right)$ samples were collected from a former mine in Kharidhunga, approximately $80 \mathrm{~km}$ from Kathmandu.

\subsection{Reactors}

Sedimentation Reactor: A first reactor design was developed using a common $50 \mathrm{~L}$ polypropylene tank, which is widely available and popular throughout Nepal. To keep the necessary modifications to a strict minimum, the tank was only fitted with two plastic outlet taps at the bottom. The top of the tank was fitted with a metal stirring mechanism with two stirrer paddles and a metal crank (Figure 1). After the addition of the appropriate magnesium dose (molar ratio $1.1 \pm 0.1 \mathrm{~mol} \mathrm{Mg} \cdot \mathrm{mol} \mathrm{P}^{-1}$ ), the urine-magnesium solution was stirred for 10 minutes (previous work (Etter, 2009) indicated that this was the optimal reaction time). Since Nepal suffers from acute electricity shortages (up to 16 hours daily), the struvite reactors were designed to be operable without electricity. After approximately 6 hours, the precipitated struvite had settled on the reactor's bottom, where it was retained in a flat tray fitted with a cloth filter. Following the sedimentation period, the higher of the two outlet taps was opened to drain the supernatant. The filter tray was then lifted out of the reactor and the struvite cake was dried at ambient temperature to form a powder. 


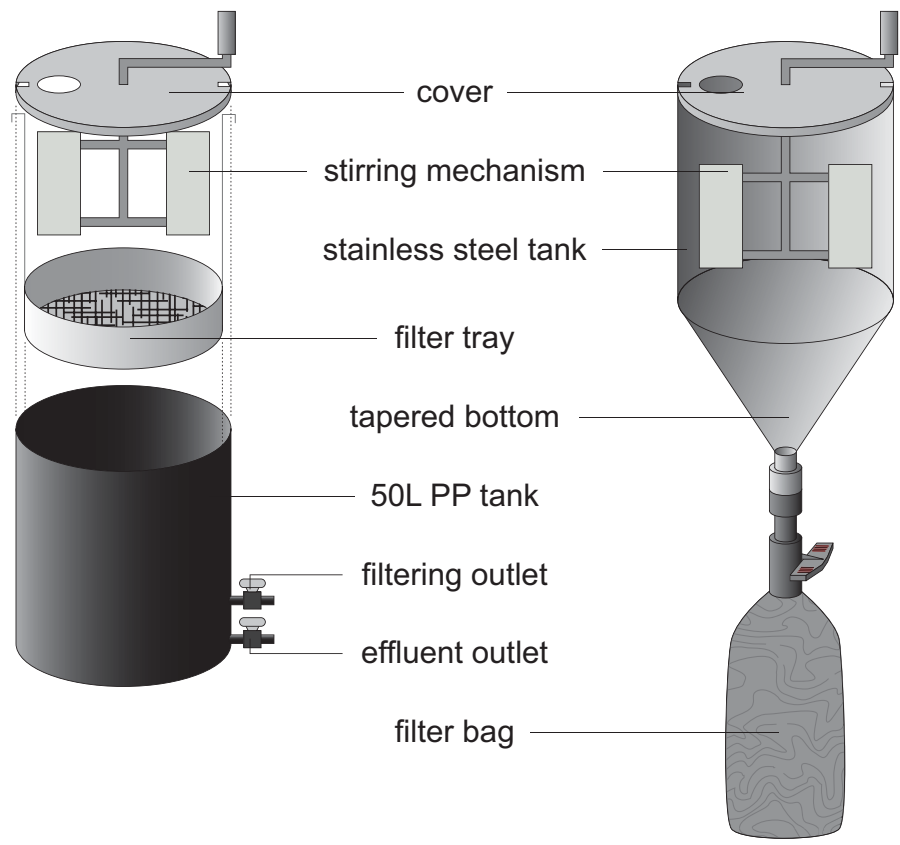

Figure 1: The two reactor setups tested for struvite production from urine: sedimentation reactor (left) and filtration reactor (right).

Filtration Reactor: Because of low phosphorus recovery, the sedimentation reactor was shown to be inadequate and after several months of testing, an improved reactor was developed. Because sheet metal workshops can be found all through the Kathmandu Valley, a slightly more sophisticated reactor was produced from galvanized sheet metal instead of plastic (plastic processing for larger installations is not accessible in Nepal). The filtration reactor consisted of a cylindrical drum (50 L) with a conical bottom. From the lower central outlet, a polypropylene (PP) pipe led through a sturdy ball valve (Nepatop) to a filter bag with a filtering surface of approximately $0.2 \mathrm{~m}^{2}$ (Figure 1). Just like the sedimentation reactor, the filtration reactor was also fitted with a welded metal stirring mechanism. Nylon (pore size $160 \pm 50 \mu \mathrm{m}$ ) was selected as the filter material, for reasons of resistance and longevity. Following the addition of magnesium (molar ratio $1.1 \pm 0.1 \mathrm{~mol} \mathrm{Mg} \cdot \mathrm{mol}^{-1}$ ) and subsequent precipitation (during 10 minutes of continuous stirring), the crystals were separated from the liquid by opening the valve at the bottom of the reactor tank and allowing the struvite-urine solution to pass into the hanging filter bag. The retained filter cake was dried at ambient temperature.

\subsection{Flocculation experiments}

To determine the effect of flocculants on struvite recovery, 10 $\mathrm{mL}$ of bittern (275 $\mathrm{mg}$ of dissolved magnesium) were added to identical glass columns filled with $1 \mathrm{~L}$ of stored urine and mixed continuously for 10 minutes using a magnetic stirrer. Five different flocculants were tested according to the manufacturer's recommended concentrations or according to literature values: alum $\left(\mathrm{Al}_{2}\left(\mathrm{SO}_{4}\right)_{3} \cdot 10 \mathrm{H}_{2} \mathrm{O}, 500 \mathrm{mg} \cdot \mathrm{L}^{-1}\right)$, lime $\left(\mathrm{Ca}(\mathrm{OH})_{2}, 100 \mathrm{mg} \cdot \mathrm{L}^{-1}\right)$, two synthetic polyelectrolytes (cationic polyamine, Ensola 2001, $10 \mathrm{mg} \cdot \mathrm{L}^{-1}$; anionic polyacrylamide, Ensola $2051,10 \mathrm{mg} \cdot \mathrm{L}^{-1}$ ) and a natural product: moringa oleifera (prepared at two concentrations from dried seeds in a food blender, $50 \mathrm{mg} \cdot \mathrm{L}^{-1}$ and $500 \mathrm{mg} \cdot \mathrm{L}^{-1}$ ). The flocculants were added to the magnesium-dosed urine and, to prevent the destruction of crystals, while ensuring the incorporation of flocculants, the stirring was continued at a lower speed for another 2 minutes. In addition to the columns where the flocculants were added, a blank sample of urine with only a bittern addition (i.e. without a flocculent addition) was prepared. The pipette method, as is common in soil science, was used to compare the sedimentation rates: $25 \mathrm{~mL}$ aliquots were taken at a $10 \mathrm{~cm}$ depth (Burt, 2004) at the start of the experiment, and then after 10 minutes, 1 hour, and 1 day. The samples were dried at $105{ }^{\circ} \mathrm{C}$ for 24 hours prior to weighing, in order to determine the total solids content. Heating struvite above $55^{\circ} \mathrm{C}$ causes a gradual mass loss (Bhuiyan et al., 2008) due to ammonia and water dissociation. Therefore, the final mass after drying does not correspond to the potentially recoverable struvite mass. In the experiment with moringa seeds, a control column containing only stored urine without a bittern addition was also dosed with moringa to determine the effect, if any, on urine without induced struvite formation

\subsection{Filtration}

As the urine passes through the filter bag, the struvite is retained and forms a filter cake. The influence of the struvite cake on the removal efficiency was investigated: outflow samples from the filter were taken 1, 2, 5, 10 and 20 minutes after the urine was mixed with magnesium. The nylon filter bag provided approximately $2000 \mathrm{~cm}^{2}$ of filter surface $\left(40 \mathrm{~cm}^{2}\right.$ per litre of reactor volume). The total phosphate was measured and the total outflow volume was monitored.

\subsection{Granulation}

Granulation of struvite from the filtration reactor was tested at laboratory scale using a stainless steel rotating drum with a diameter of $0.2 \mathrm{~m}$. Besides water, no other binding agents were added. Initially, $50 \mathrm{~g}$ of struvite powder produced from urine in the filtration reactor was added to the revolving drum, and water was injected gradually using a $50 \mathrm{~mL}$ syringe, until sufficient granulation was attained. The drum was operated at a constant speed of $60 \mathrm{rpm}$. To make maximum use of locally available resources, the rotating drum was assembled using a common steel pot and an electric fan motor.

\section{RESULTS AND DISCUSSION}

\subsection{Urine quantity and quality}

The phosphorus concentration in the stored samples $\left(195 \pm 65 \mathrm{mgP} \cdot \mathrm{L}^{-1}\right)$ was considerably lower than in fresh urine $\left(388 \pm 251 \mathrm{mgP} \cdot \mathrm{L}^{-1}\right)$ (refer to Table 1 for a comparison). The measured values are at the lower end of the range of literature data (e.g. 370 to $740 \mathrm{mgP} \cdot \mathrm{L}^{-1}$, Tilley et al., 2008b; Udert et al., 2003a). The low phosphate concentration in stored urine can be explained by precipitation. A valuable part of the phosphate - in undiluted urine about 30\% (Udert et al. 2003b; Tilley et al., 2008c) - precipitates spontaneously as calcium phosphate and struvite when urea is hydrolyzed by urease during storage. To validate the difference between fresh and stored urine, the residual phosphate in stored urine was estimated assuming that all magnesium and all calcium in fresh urine (Table 1) precipitated spontaneously as struvite or octacalcium phosphate $\left(\mathrm{OCP}, \mathrm{Ca}_{8} \mathrm{H}_{2}\left(\mathrm{PO}_{4}\right)_{6} \cdot 5 \mathrm{H}_{2} \mathrm{O}\right)$ as suggested by Udert et al. (2003a). The phosphate incorporated in the minerals was then subtracted from the amount of dissolved phosphate. Based on this calculation, at least $28 \%$ of the initial phosphate precipitated (13\% as OCP, $15 \%$ as struvite) leaving a residual concentration of $279 \mathrm{mgP} \cdot \mathrm{L}^{-1}$. The difference between the calculated phosphate concentration and the measured value (195 $\mathrm{mg} \mathrm{P} \cdot \mathrm{L}^{-1}$ ), is likely due to the addition of flushing water, 
Table 1: Average concentration of selected compounds in fresh urine (14 samples, 8 male, 6 female, ages between 6 and 64) and stored urine from UDDT tanks (10 samples) in Siddhipur, Nepal.

\begin{tabular}{llllllll} 
& \multicolumn{9}{c}{ Fresh Urine } & \multicolumn{3}{c}{ Stored Urine } \\
ion & unit & av & st dev & med & av & st dev & med \\
\hline $\mathrm{NH}_{4}-\mathrm{N}$ & {$\left[m g \cdot L^{-1}\right]$} & 438 & 207 & 418 & & & \\
Urea & {$\left[m g \cdot L^{-1}\right]$} & 4450 & 1730 & 4420 & & & \\
$\mathrm{PO}_{4}-\mathrm{P}$ & {$\left[\mathrm{mg} \cdot \mathrm{L}^{-1}\right]$} & 388 & 251 & 383 & 195 & 65 & 170 \\
$\mathrm{Cl}$ & {$\left[\mathrm{mg} \cdot \mathrm{L}^{-1}\right]$} & 6620 & 2390 & 6410 & & & \\
$\mathrm{SO}_{4}$ & {$\left[\mathrm{mg} \cdot \mathrm{L}^{-1}\right]$} & 878 & 379 & 822 & & & \\
$\mathrm{CO}_{3}$ & {$\left[\mathrm{mg} \cdot \mathrm{L}^{-1}\right]$} & 8.53 & 2.16 & 7.60 & & & \\
$\mathrm{COD}^{2}$ & {$\left[\mathrm{mg} \cdot \mathrm{L}^{-1}\right]$} & 7660 & 4630 & 6340 & & & \\
$\mathrm{Mg}$ & {$\left[\mathrm{mg} \cdot \mathrm{L}^{-1}\right]$} & 45.4 & 22.9 & 36.9 & & & \\
$\mathrm{Ca}$ & {$\left[\mathrm{mg} \cdot \mathrm{L}^{-1}\right]$} & 89.2 & 56.6 & 74.4 & & & \\
$\mathrm{~K}$ & {$\left[\mathrm{mg} \cdot \mathrm{L}^{-1}\right]$} & 1870 & 976 & 1940 & & & \\
$\mathrm{Na}$ & {$\left[\mathrm{mg} \cdot \mathrm{L}^{-1}\right]$} & 3240 & 1230 & 3270 & & & \\
$\mathrm{pH}$ & {$[-]$} & 5.6 & 0.4 & 5.5 & 9.0 & 0.1 & 8.9 \\
$\mathrm{EC}$ & {$\left[\mathrm{ms} \cdot \mathrm{cm} m^{-1}\right]$} & 22.6 & 6.3 & 23.5 & 25.9 & 3.9 & 25.8 \\
\hline
\end{tabular}

* Electrical Conductivity is temperature corrected

which not only dilutes the urine but also induces additional precipitation by adding magnesium and calcium (Udert et al., 2003b). The rather small difference between the measured and calculated phosphate concentrations suggests that the dilution with flushing water was low.

With the stored urine collected in our study, $1 \mathrm{~kg}$ struvite could have been produced from $640 \mathrm{~L}$ urine. However, the yield of solid phosphate could have been increased by at least $40 \%$, if the spontaneously precipitated struvite and OCP were completely recovered as well. Since struvite and calcium phosphate are both good phosphate fertilizers (UNIDO, 1998), collecting spontaneously precipitated phosphate increases the overall fertilizer recovery from urine.

\subsection{Estimation of phosphate concentration in stored urine}

In struvite production, the phosphate concentration in the process influent (i.e. urine) must be known as exactly as possible, in order to facilitate an optimal magnesium dosage. Estimating the phosphate concentration is also needed for accurate financial compensation for urine deliveries. Since electrical conductivity measurements have proven to be a rapid and cost-efficient tool for online phosphate monitoring in biological processes (Wylie, 2009; Maurer and Gujer, 1995), we adapted the method for the use with urine. The temperature compensated electrical conductivity $\left(25^{\circ} \mathrm{C}\right)$ and phosphate concentration were determined in ten samples of stored urine and plotted against each other. The samples originated from the storage tanks of different UDDTs in Siddhipur and were taken during the 3 months field research. The results (Figure 2 ) show a very good correlation $\left(r^{2}=0.94\right)$. Within the measured range, the phosphorus content can be estimated using Equation 1:

Equation 1: $\quad\left[\mathrm{PO}_{4}-\mathrm{P}\right]=15 \cdot \mathrm{EC}_{25^{\circ} \mathrm{C}}-200$

where the temperature compensated electrical conductivity $\mathrm{EC}_{25^{\circ} \mathrm{C}}$ is measured in $\mathrm{mS} \cdot \mathrm{cm}^{-1}$ and the phosphate concentration $\left[\mathrm{PO}_{4}-\mathrm{P}\right]$ is given in $\mathrm{mg} \mathrm{P} \cdot \mathrm{L}^{-1}$.

For the samples analyzed (phosphate concentrations were

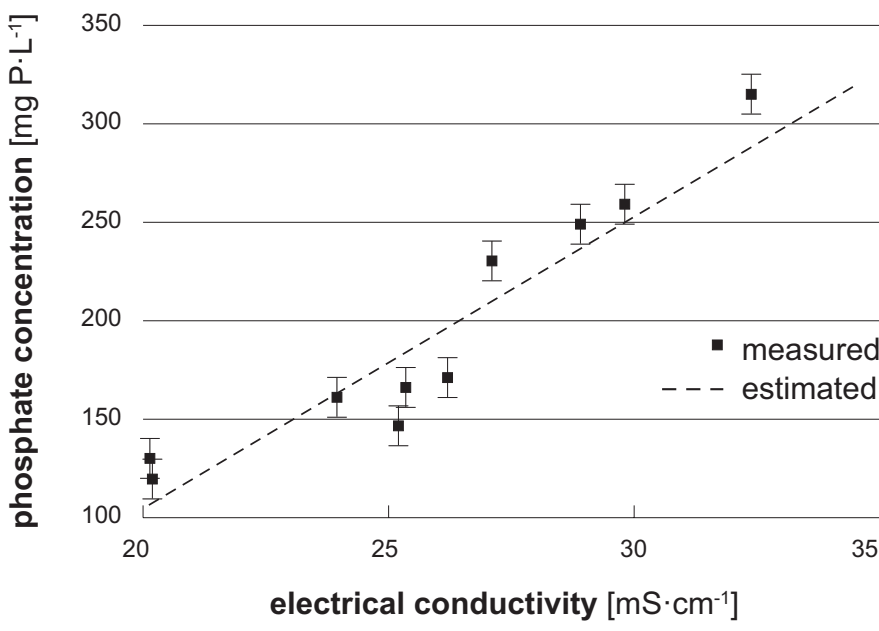

Figure 2: Correlation between electrical conductivity (compensated for $25^{\circ} \mathrm{C}$ ) and phosphate concentration. The error bars depict standard deviations of the phosphate measurements by photo-spectrometry.

between 119 and $315 \mathrm{mg} P \cdot \mathrm{L}^{-1}$ ), the standard deviation for the determination of phosphate via electrical conductivity was $\pm 22 \mathrm{mg} \mathrm{P} \cdot \mathrm{L}^{-1}$ with respect to the photo-spectrometric analysis. This standard deviation is considerably lower than the standard deviation determined for the average phosphate concentration without linear correlation (65 mgP. $\mathrm{L}^{-1}$, see Table 1), which means that estimating the phosphate concentration with Equation 1 results in a significantly more accurate value than just using the average phosphate concentration.

Estimating the phosphate concentration via electrical conductivity has important advantages over the direct chemical determination of phosphate: it delivers an instantaneous result, it is much cheaper and it does not require careful handling of chemicals. However, the correlation between phosphate and electrical conductivity should be validated for every community anew to account for differences in the urine collection (e.g. composition changes due to ammonia volatilization).

\subsection{Magnesium sources}

Table 2 summarizes the estimated costs of the three magnesium sources magnesium sulphate fertilizer, bittern and pretreated magnesite rock. The most common precipitant for laboratory experiments, magnesium chloride (Liu et al., 2008; Ronteltap et al., 2007) and magnesium oxide (Wilsenach et al., 2007), were not considered because both were only available through laboratory suppliers. Our estimation shows that magnesium oxide produced from locally available magnesite would incur the least costs (12 NRs $\cdot \mathrm{kg}$ struvite-1). Bittern (22 NRs $\cdot \mathrm{kg}^{-1}$ struvite $^{-1}$ ) and magnesium sulphate (37 NRs. kg struvite ${ }^{-1}$ ) are two- and three-times as expensive, respectively. Bittern is the waste brine remaining after salt $(\mathrm{NaCl})$ extraction from seawater. It has been suggested as a suitable magnesium source due to its high residual magnesium content, which ranges from $31 \mathrm{~g} \cdot \mathrm{L}^{-1}$ to $64 \mathrm{~g} \cdot \mathrm{L}^{-1}$ (Lozano et al., 1999; El Diwani et al., 2007; Lee et al., 2003). Our sample was directly obtained from the Jakhau Salt Company in Gujarat, India, and contained about $27.5 \mathrm{~g} \cdot \mathrm{L}^{-1}$ magnesium (though magnesium concentrations of up $85 \mathrm{~g}^{\cdot \mathrm{L}^{-1}}$ have been achieved at the Jakhau Salt Company (Venkataraman, 2010)). Although bittern is a waste product and can be obtained for free at the 
Table 2: A comparison of the magnesium sources tested for struvite production in Nepal. Prices are given in Nepalese Rupees [NRs]. 100 NRs are about 1 Euro.

\begin{tabular}{|c|c|c|c|}
\hline & Magnesium sulphate & Magnesite & Bittern \\
\hline Magnesium compound & $\mathrm{MgSO}_{4} \cdot 7 \mathrm{H}_{2} \mathrm{O}$ & $\mathrm{MgCO}_{3}$ & $\mathrm{Mg}^{2+}$ \\
\hline Required input [kg·kg struvite $\left.{ }^{-1}\right]$ & 1.10 & 0.41 & 1.43 \\
\hline Required pre-treatment & - & calcination & - \\
\hline Appr. raw cost [NRs·kg Mg-1] & $320^{c}$ & $32^{c}$ & 0 \\
\hline Transportation cost [NRs $\left.\cdot \mathrm{kg} \mathrm{Mg}^{-1}\right]^{\mathrm{e}}$ & 22 & 3 & 205 \\
\hline Total cost [NRs $\left.\cdot \mathrm{kg} \mathrm{Mg}^{-1}\right]$ & 342 & 111 & 205 \\
\hline Total input cost [NRs $\cdot k g$ struvite $\left.{ }^{-1}\right]^{\dagger}$ & 37 & 12 & 22 \\
\hline $\begin{array}{l}\text { Major advantages } \\
\text { waste recycling }\end{array}$ & available on the market & local resource & easy dosage \\
\hline
\end{tabular}

a measured by the authors ( $n=1$; method standard deviation $=5 \%$ )

${ }^{b}$ highest achieved concentration by the Jakhau Salt Company (Venkataraman, 2010).

${ }^{c}$ as quoted by Everest Yeti International P. Ltd., Kathmandu, Nepal (August 2008)

d Calculated with: theoretical energy demand for MgO production $2415 \mathrm{~kJ} / \mathrm{kg} \mathrm{MgCO}$ (Shand, 2006), burning efficiency $35 \%$ (conventional shaft kiln; UN Habitat, 1993 ), net calorific value of heating oil $42.6 \mathrm{MJ} / \mathrm{kg}$ (DIN 51603-1), density of heating oil at $15^{\circ} \mathrm{C} 0.86 \mathrm{~g} / \mathrm{L}$ (DIN 51603-1), diesel price $70 \mathrm{NRs} / \mathrm{L}$ (October 2008 ) $60 \%$ of total costs are for fuel (UN Habitat, 1993).

e Calculated with the rates charged for transport between Birganj and Kathmandu (2.14 NRs. $\mathrm{kg}^{-1}$ for $270 \mathrm{~km}$; November 2008). Magnesium sulphate is transported from the border (Birganj) to Kathmandu (270 km), magnesite from the mine (Kharidhunga, $80 \mathrm{~km}$ ) and bittern from Gujarat/India to Kathmandu (2200 km)

${ }^{\mathrm{f}}$ Assuming a magnesium dosage of $1.1 \mathrm{~mol} \mathrm{Mg} \cdot \mathrm{mol} \mathrm{P}^{-1}$

source, transport costs are high. One important consideration for imported magnesium sources (bittern and magnesium sulphate) is that of trade restrictions, which make locally produced magnesium oxide an interesting alternative. Although magnesium oxide is not currently produced in the vicinity of Kathmandu, high quality magnesite $\left(\mathrm{MgCO}_{3}\right)$ deposits are available in Kharidhunga, approximately $80 \mathrm{~km}$ from Kathmandu. Until 1990, a mine was operated in Kharidhunga and dead burnt magnesite with a $\mathrm{MgO}$ content of 88 to $96 \%$ was produced (Wu, 1994). Since magnesite hardly dissolves in water, it must be converted into a reactive magnesium compound such as magnesium oxide before it can be used for struvite precipitation. Magnesium oxide can be produced by calcining the mined magnesite rock at elevated temperatures (Shand, 2006). Based on fuel consumption and efficiency data for conventional kilns (burning efficiency 35\%; UN Habitat, 1993) the calcination of $1 \mathrm{~kg} \mathrm{MgCO}{ }_{3}$ would require about $0.2 \mathrm{~L}$ diesel.

When choosing a magnesium source, one must also consider the addition of compounds other than magnesium. We calculated the change of the major compounds in the urine matrix for bittern and magnesium sulfate additions. For the calculation, we used the matrix of fresh urine, the measured composition of bittern (Table 3) and the theoretical $\mathrm{MgSO}_{4}$ stoichiometry. The calculations showed that the magnesium sulfate addition $(1.1 \mathrm{~mol} \mathrm{Mg} \cdot \mathrm{mol}$ $\mathrm{P}^{-1}$ ) changes the urine matrix drastically. $\mathrm{A} \mathrm{MgSO}_{4}$ addition would result in a sulfate concentration increase of $76 \%$, while bittern would cause only slight increases of chloride $(1.0 \%)$, sulfate $(1.7 \%)$, potassium $(2.6 \%)$ and sodium $(13 \%)$. The calculation was not done for $\mathrm{MgO}$, because the product was not available yet. Pure $\mathrm{MgO}$, however, contains only oxygen as an additional compound and therefore would hardly change the composition of urine. The final $\mathrm{MgO}$ sources (as well as bittern and $\mathrm{MgSO}_{4}$ ) also has to be analyzed for heavy metals, before choosing one of the magnesium sources for large scale struvite production.

\subsection{Reactor efficiencies}

The phosphate removal efficiency was determined by comparing the phosphate concentrations in the influent and effluent of the reactor. The sedimentation reactor (Figure 1) achieved only about $50 \%$ phosphate removal. Slow crystallization was not the reason for the low removal, as lab experiments showed that a reaction time of 10 minutes was sufficient to precipitate $95 \%$ of phosphate as struvite. The low removal was mainly due to the inefficient solids recovery caused by an inadequate filtering process: small particles were easily lost through the gap between the reactor wall and the filter tray or when the tray was lifted. Since the retention of solids through the liquid-solid separating

Table 3: Measured composition of bittern from the Jakhau Salt Company, Gujarat, India.

\begin{tabular}{lrrrrr} 
ion & $\mathrm{Cl}^{-}$ & $\mathrm{SO}_{4}{ }^{2-}$ & $\mathrm{Mg}^{2+}$ & $\mathrm{K}^{+}$ & $\mathrm{Na}^{+}$ \\
\hline concentration $\left[\mathrm{g} \cdot \mathrm{L}^{-1}\right]$ & 17.4 & 3.3 & 27.5 & 1.9 & 3.2 \\
\hline
\end{tabular}

Table 4: Comparison of the struvite reactors. Prices are given in Nepalese Rupees [NRs]. 100 NRs are about 1 Euro.

Liquid-solid separation

\begin{tabular}{lll}
\hline Design parameter & sedimentation & filtration \\
\hline Volume & $50 \mathrm{~L}$ & $50 \mathrm{~L}$ \\
Installation costs & $3,500 \mathrm{NRs}$ & $6,000 \mathrm{NRs}$ \\
Phosphate removal efficiency $50 \%$ & $90 \%$ \\
Average treatment cycle & $12 \mathrm{hours}$ & $1 \mathrm{hour}$ \\
Daily treatment capacity & $50 \mathrm{~L}$ & $400 \mathrm{~L}$ \\
Filter surface & $1,000 \mathrm{~cm}^{2}$ & $2,000 \mathrm{~cm}^{2}$ \\
Reactor tank material & polypropylene & galvanized steel \\
\hline
\end{tabular}




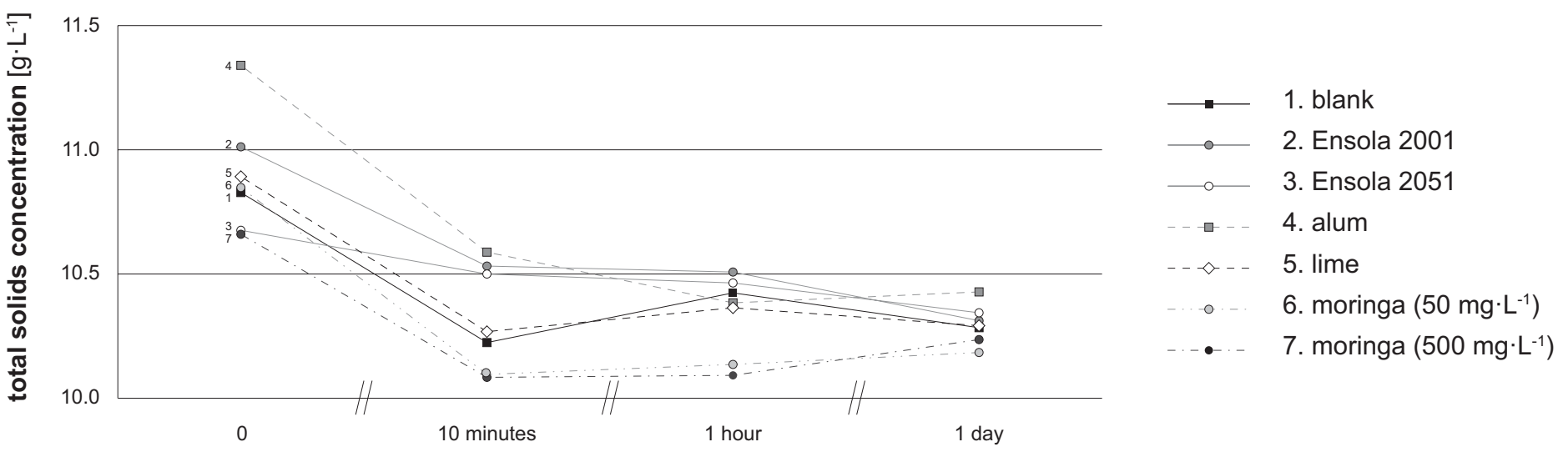

Figure 3: Total solids concentration from the urine-struvite suspension at a depth of $10 \mathrm{~cm}$ versus time for various flocculants.

mechanism of the sedimentation reactor was insufficient, the filtration reactor was constructed. Successive field tests with the external filter bag demonstrated a phosphate removal efficiency of up to $91 \%$. This efficiency was much higher than in the sedimentation reactor, but slightly lower than in lab experiments with the same magnesium:phosphate ratio, probably due to some loss of phosphate through the nylon bag (see the discussion on filtration). The removal efficiency could be increased further with larger molar Mg:P ratios.

Abegglen (2008) reported that in lab experiments with stored urine and magnesium oxide as precipitant, a minimum molar ratio of $1.2 \mathrm{~mol} \mathrm{Mg} \cdot \mathrm{mol} \mathrm{P}^{-1}$ was required to remove at least $95 \%$ of the phosphate. Abegglen (2008) and Antonini et al. (2009) achieved phosphate removal efficiencies with filter bags of more than $95 \%$, but they added $1.8 \mathrm{~mol} \mathrm{Mg} \cdot \mathrm{mol} \mathrm{P}^{-1}$ and $1.5 \mathrm{~mol} \mathrm{Mg} \cdot \mathrm{mol} \mathrm{P}^{-1}$, respectively, and the filter bags probably had much smaller pore widths. A reactor of the same type currently installed at the headquarters of the Deutsche Gesellschaft für Technische Zusammenarbeit (GTZ) in Eschborn, Germany is operated with filter bags that have pore widths of 5 to $10 \mu \mathrm{m}$ (Heynemann, 2010).

The time to process $50 \mathrm{~L}$ of urine could also be reduced from more than 6 hours (required for the sedimentation method) to about 1 hour in the filtration reactor. The total construction costs was $3500 \mathrm{NRs}(35 €)$ for the sedimentation reactor, and 6000 NRs $(60 €)$ for the filtration reactor (including labour). For a comparison of the two reactor models refer to Table 4.

Several research groups identified scaling inside the struvite reactor as one of the major problems for struvite production (Wilsenach et al., 2007; Abegglen, 2008; Ronteltap et al. 2010). In our experiments, scaling mainly occurred in the sedimentation reactor, were a small layer of struvite on the reactor wall was detected soon after the experiments started. However, in the filtration reactor, hardly any scaling was observed after more than 50 batches ( $2500 \mathrm{~L}$ urine). The reduced scaling in the filtration reactor is probably due to the much lower retention time of the urine in the reactor vessel: the overall treatment time including stirring and filtration was one hour. Abegglen (2008) reported that scaling problems (especially clogging of the effluent valve) could be prevented if the sedimentation time was shorter than four hours.

\subsection{Flocculation experiments}

The addition of flocculants was tested as a means to improve the solids retention of the sedimentation reactor. Flocculants are commonly used to improve settleability of organic and inorganic solids in wastewater treatment (Tchobanoglous et al., 2004). The most common flocculants are inorganic compounds or synthetic polyelectrolytes. In the case of struvite, the cationic polyacrylamine (Ensola 2001, Ensola GmbH, Wetzikon, Switzerland) was assumed to be the most effective, because struvite particles have a strong negative surface charge (Le Corre et al., 2007). Ground moringa oleifera seeds are a novel flocculant, which have been tested for COD (Bhuptawat et al., 2007) and turbidity removal (Katayon et al., 2006) in water or wastewater treatment. We do not know of work which has addressed the removal of nutrients, such as nitrogen or phosphorus, with the addition of moringa oleifera seeds.

As anticipated, the absolute total solids content in the $1 \mathrm{~L}$ columns increased with the addition of flocculants (data not shown). To compare the solids removal, the total solids concentration was measured at several times at a depth of $10 \mathrm{~cm}$ (Figure 3). After a 10 minute sedimentation period, only alum had achieved a higher total solids decrease than the blank sample. Initially, the cationic flocculant (Ensola 2001) did not affect sedimentation, whereas the anionic flocculant (Ensola 2051) actually slowed down settling. After 1 hour, and again after 1 day of sedimentation time, all the total solid concentrations at a depth of $10 \mathrm{~cm}$ were similar: between 10.18 and $10.43 \mathrm{~g}^{\cdot \mathrm{L}^{-1}}$ (the blank sample's total solid concentration was $\left.10.28 \mathrm{~g} \cdot \mathrm{L}^{-1}\right)$. Thus, it was concluded that the addition of flocculants is not a suitable method for improving struvite recovery in the sedimentation reactor.

\subsection{Filtration}

The filter efficiency of the nylon bag on the filtration reactor was measured as a function of filtration time. The struvite had been produced by adding bittern in a molar ratio of $1.1 \mathrm{~mol} \mathrm{Mg} \cdot \mathrm{mol} \mathrm{P}^{-1}$, and by stirring for 10 minutes before opening the valve. The results showed that the phosphate concentration in the struvite effluent decreased with an increase in filtered volume (Figure 4). As a control, the individual phosphate concentrations of each sample (corresponding to the indicated time) were integrated over the percolated liquid volume (Equation 2).

Equation 2: $\quad\left[\mathrm{PO}_{4}-\mathrm{P}\right]=\left(\Sigma\left[\mathrm{PO}_{4}-\mathrm{P}\right]_{\mathrm{i}} \cdot \Delta \mathrm{V}_{\mathrm{i}}\right) / \mathrm{V}_{\text {total }}$

where $\left[\mathrm{PO}_{4}-\mathrm{P}\right] \mathrm{i}$ is the instantaneous phosphate concentration measured in the partial volume $\Delta \mathrm{V}_{i}$ at time $\mathrm{t}_{\mathrm{i}}$. The calculated phosphate concentration agrees well with the final phosphate concentration measured in the mixed effluent tank (90\% reduction of phosphate concentration from process influent to effluent). 


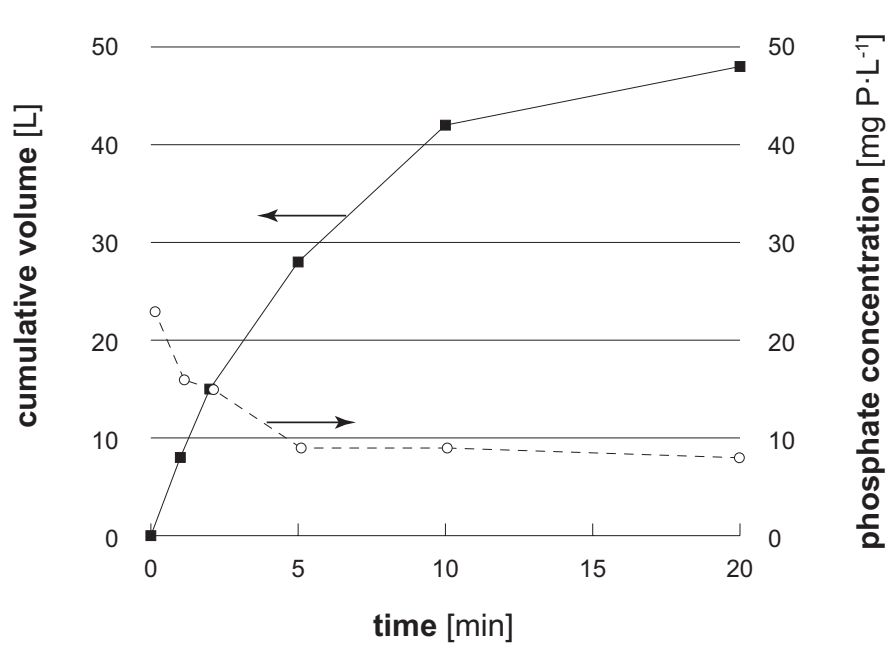

Figure 4: The decreasing phosphate concentration at the reactor's outlet at an increasing cumulative filtrate volume $(50 \mathrm{~L}$ treated urine) illustrates the importance of the filter cake in the filtration process.

Measurements by Ronteltap et al. (2010) using a batch reactor with a propeller stirrer, showed that the average struvite particle diameter was $92 \mu \mathrm{m}$. This is actually smaller than the maximum pore width of the nylon filter $(160 \pm 50 \mu \mathrm{m})$. The good phosphate removal (more than $90 \%$ ) must be due to the build-up of a filter cake. With accumulating particles, the permeability of the filter cake decreases, smaller particles are retained, and particles of considerably lower diameters than the filter's pore size are therefore held on the filter (Cheremisinoff, 1998). Our experiments show that using filter bags with large pore widths can achieve high struvite recoveries, while keeping the filtration time short.

\subsection{Granulation}

Most fertilizers are marketed in a granulated form because a powder is not user-friendly, there is a risk of caking if exposed to moisture, and powder does not withstand aeolian transport once applied to agricultural surfaces. We used struvite powder produced in the filtration reactor to test whether granulation could be achieved in a simple rotating drum. After an initial nucleation phase with water as a binding agent, the particles grew quickly by assimilating remaining particles of lower diameter, as was described by Adetayo et al. (1993). If the water was injected into the drum gradually over five minutes, a higher number of small diameter granules $(<2 \mathrm{~mm})$ formed.

After more than 6 months of storage in a closed container, the formed granules still maintained their size and shape. When processing greater volumes of struvite slurry, a sieving mechanism would be required to ensure a uniform particle size distribution of the final product.

\subsection{Economic efficiency of struvite production}

One important idea behind struvite recovery is the use of the financial value of the nutrients in urine for the promotion of sanitation. Ideally, the sale of the struvite produced would cover all the costs or even generate profit. Based on the data collected in this project, we did a first estimate of the financial efficiency of struvite production (Table 5). We chose a reactor of $500 \mathrm{~L}$ assuming that one person should still be able to operate the reactor alone. The magnesium dosage was set to $1.1 \mathrm{~mol} \mathrm{Mg}$ per $\mathrm{mol} \mathrm{P}$ and the struvite recovery efficiency was assumed to be $90 \%$, which would yield $1 \mathrm{~kg}$ struvite from $720 \mathrm{~L}$ stored urine in Siddhipur. As cost factors, we considered the amortization and capital costs for the reactor and the expenses for the magnesium sources.

The revenue was solely based on the sale of struvite and did not take into account the public benefits related to health or the environment. The market value of the nutrients was taken from the work presented by Tilley et al. (2009), which is based on a market survey of 16 different fertilizer products in Siddhipur. Based on a regression analysis, the struvite market value is between 25 and $57 \mathrm{NRs} \cdot \mathrm{kg}^{-1}$ with a best estimate of $41 \mathrm{NRs} \cdot \mathrm{kg}^{-1}$. Our estimate shows that treating $4000 \mathrm{~L}$ stored urine per day yields a maximum net profit of $32,000 \mathrm{NRs} \cdot \mathrm{a}^{-1}$ if magnesite is used as the magnesium source. $\mathrm{MgSO}_{4}$ is too expensive to generate a net profit and the use of bittern results in about half the profit generated by using magnesite. This comparison clearly shows the importance of finding a cheap and efficient magnesium source. However, with cheap, locally produced $\mathrm{MgO}$, the profit of struvite sales would be too low to cover a basic wage $400 \mathrm{NRs}^{-1} \mathrm{~d}^{-1}(100,000$ $\mathrm{NRs} \cdot \mathrm{a}^{-1}$ ); three times more urine would have to be treated, which is about $12 \mathrm{~m}^{3}$ or the urine excreted by 10,000 people per day.

The struvite recovery scheme has to be improved to become financially sustainable. Collecting spontaneously precipitated struvite and calcium phosphate from the urine collection tanks would increase the phosphate recovery by at least $40 \%$ (see urine quality and quantity). Therefore, the UDDTs should be constructed such that the pipe to the tank is as short as possible to ensure that spontaneous precipitation occurs in the tank and not in the pipe. The choice of location will also have a strong influence on whether struvite recovery will be economically feasible. To prevent additional costs for transportation, urine treatment reactors should be installed at locations where large volumes of urine are generated (e.g. markets, bus stations, public buildings etc.). In public toilets, additional revenues can be created if the users pay a small fee. Struvite production could also be promoted directly by the state, considering that struvite production from urine also helps to prevent environmental pollution by phosphorus.

\subsection{Effluent treatment}

Although stripped of phosphorus, effluent is still rich in ammonium, potassium and sulfur. From the balance in Figure 5 it can be seen that the effluent has about four times the monetary value of struvite, mainly due to nitrogen and potassium. To maximize the value of urine, and mitigate the potentially harmful effects of discharging a liquid with a high eutrophication potential into water bodies, these nutrients should be re-used. The easiest way to recover the nutrients from the effluent is through direct application to agricultural soils.

Because direct application of urine (or ,process effluent') using buckets or watering cans results in high losses of ammonia to volatilization, we applied the process effluent to crops through a drip irrigation system, which not only prevented ammonia loss but also clogged less than using urine, since all of the minerals with a precipitation potential, had been removed (Kashekya, 2009). However, direct use of the effluent is probably restricted to very few locations, where high population densities and large areas of agricultural land coincide. As an alternative to drip irrigation, the effluent may be treated using additional physical and/or biological processes, such as a combination of nitrification and evaporation (Udert and Wächter, 2010). The recovery of remaining nutrients, particularly nitrogen, potassium and sulfur, will be important if the true value of the nutrients contained in urine is to be maximized. This work requires further attention and is underway in both the lab and in the field. 


\section{CONCLUSIONS}

With this project, we could show that an efficient and reliable struvite reactor can be built in Nepal with locally available materials and at a low cost ( $60 €$ for a $50 \mathrm{~L}$ reactor). Filtration resulted in much higher phosphate recoveries than sedimentation; more than $90 \%$ of phosphate could be recovered, using only little magnesium (dosage ratio $1.1 \mathrm{~mol} \mathrm{Mg} \cdot \mathrm{mol} \mathrm{P}^{-1}$ ) and a simple nylon fabric filter (pore width $160 \pm 50 \mu \mathrm{m}$ ). The accumulation of a filter cake helped to recover most of the struvite, while the large pore width still allowed for a short treatment time (one hour per cylce). The short retention time in the reactor was probably the reason why scaling on the reactor walls and the stirrer paddles was negligible. After the drying of the filter bag and granulation in a rotating drum, the end-product was an easy-to-handle, granulated, phosphate fertilizer. Currently, we are investigating the hygienic properties of struvite from urine; the high fertilizer value of struvite has been proven before.

An estimation of the financial profitability revealed that it is not possible to make struvite production self-sustaining given the current fertilizer prices, even if transport costs are kept low. While the costs for building the reactor are low, the magnesium source is expensive. The cheapest magnesium source is proba-

Table 5: Economic breakdown for struvite production based on experience and without transportation costs for urine.

\begin{tabular}{lc}
\hline Operation parameters & $500 \mathrm{~L}^{\mathrm{a}}$ \\
Reactor size & $8 \mathrm{~d}^{-1}$ \\
Cycles per day & $90 \%$ \\
Struvite recovery efficiency & $1,400 \mathrm{~kg} \mathrm{struvite} \cdot \mathrm{a}^{-1}$ \\
Yearly struvite production (250 days) & $1.1 \mathrm{~mol} \mathrm{Mg} \cdot \mathrm{mol} \mathrm{P}^{-1}$ \\
Molar Mg:P ratio & $170 \mathrm{kgMg} \cdot \mathrm{a}^{-1}$ \\
Yearly magnesium requirement & \\
\hline Installation costs $_{\text {Steel tank for reactor }}{ }^{-1}$ & $15,000 \mathrm{NRs}$ \\
Additional tanks, fittings, pipes etc. $^{\mathrm{a}}$ & $28,000 \mathrm{NRs}$ \\
Building $^{\mathrm{b}}$ & $30,000 \mathrm{NRs}$ \\
Total $^{\text {Operation duration }}$ & $73,000 \mathrm{NRs}$ \\
Amortization & $10 \mathrm{years}$ \\
Capital costs (12\%) & $7300 \mathrm{NRs} \cdot \mathrm{a}^{-1}$ \\
\hline
\end{tabular}

\section{Expenses}

Amortization and capital costs

MgSO4 price ${ }^{c}$

6 NRs.kg struvite-1

Bittern price ${ }^{\mathrm{c}}$ 37 NRs.kg struvite ${ }^{-1}$ 22 NRs.kg struvite-1

Magnesite price ${ }^{c}$ $12 \mathrm{NRs}^{\mathrm{kg}}$ struvite $^{-1}$

Revenue

Struvite market price ${ }^{d}$

Profit

Option ,MgSO4،

Option ,bittern‘

Option ,magnesite‘

$41 \mathrm{NRs} \cdot \mathrm{kg}$ struvite $^{-1}$

\footnotetext{
a Etter (2009)

b estimated

c Table 2

d Tilley et al. (2009)
}

bly magnesium oxide produced from locally minable magnesite (ca. 12 NRs $\cdot k g$ struvite ${ }^{-1}$ ). Bittern, a waste stream from salt production, has a negligible cost, but transporting it from the coast to Nepal is expensive. Magnesium sulphate fertilizer, another magnesium source available in Nepal, is too expensive for struvite production.

There are several other possibilities to reduce the cost of struvite production. First, the magnesium dosage should be as accurate as possible, for example, by using electrical conductivity to estimate the phosphate concentration. Second, the recovery of spontaneous precipitates from the collection systems can increase the overall phosphate recovery significantly; good care should be taken that the precipitates are not lost during urine collection.

Third, state sanitation programs which take into account and promote the societal and environmental benefits of phosphate removal from urine may help to increase sanitation coverage. Last but not least, struvite precipitation can only recover about $20 \%$ of the fertilizer market value from urine. A lot of the value is in ammonium and potassium, which remains in the effluent or volatilizes as ammonia. Reuse or treatment of the effluent is probably the most effective measure to increase the economic efficiency of nutrient recovery from source-separated urine.

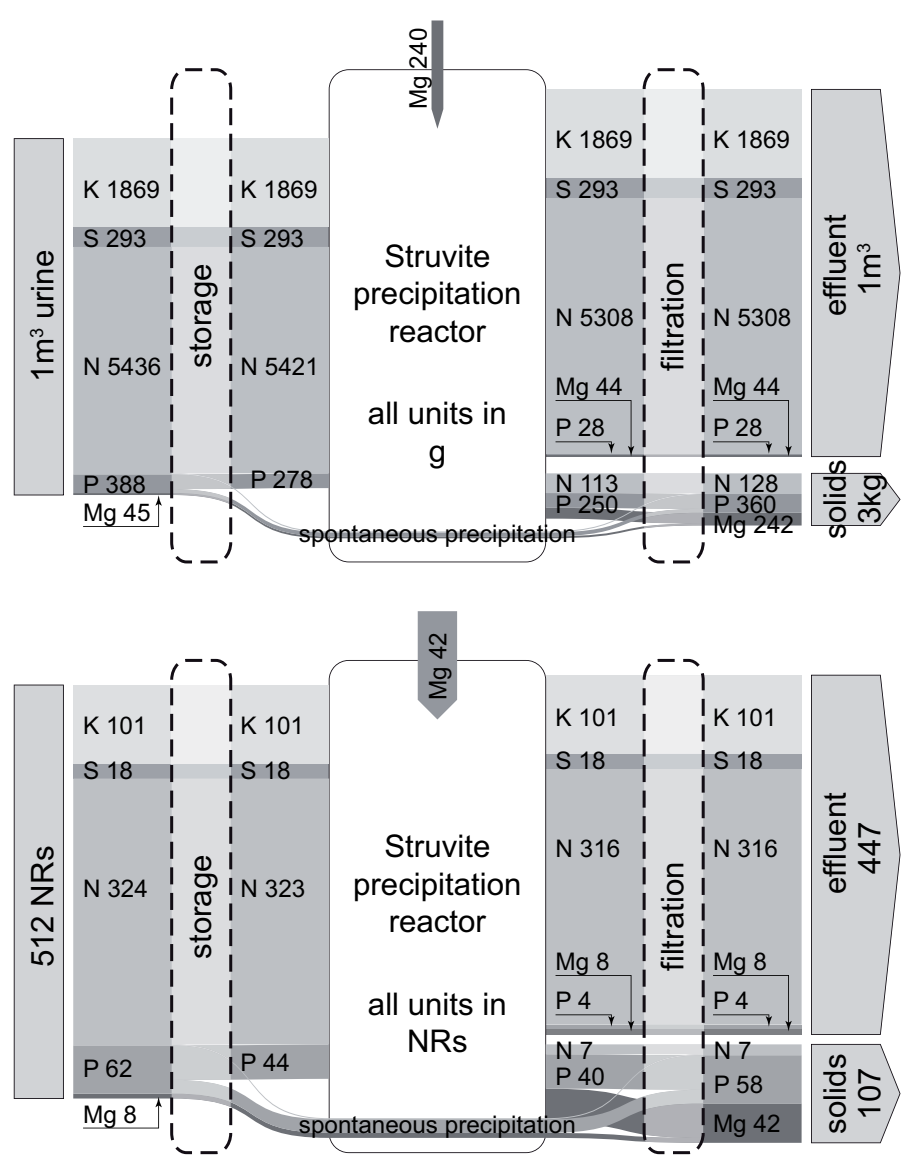

Figure 5: Mass [g] and monetary flow [NRs] (100 NRs $1 €)$ through the struvite precipitation process, assuming $90 \%$ precipitate recovery, no dilution with flushing water, no ammonia volatilization, $1.1 \mathrm{~mol} \mathrm{Mg} \cdot \mathrm{mol}^{-1}$ magnesium dosage. Fertilizer market values are based on Tilley et al., 2009. Concentrations for fresh urine are taken from Table 1, total ammonia was assumed to be $11 \%$ higher than the sum of ammonium and urea (Udert et al., 2005). 


\section{ACKNOWLEDGEMENTS}

The project was supported by Eawag discretionary funds, The Angel Fund of the Gemeinnützige Stiftung SYMPHASIS, Zürich, the Swiss Agency for Development and Cooperation (SDC) and Ingénieurs du Monde at the Swiss Federal Institute of Technology Lausanne (EPFL). The funding sources were neither involved in the study design, nor the collection, analysis or interpretation of the data. Much of this work would not have been possible without contributions from Basil Gantenbein, Edmund John Kashekya and Mingma Sherpa, and the logistical support from UNHABITAT Nepal. The authors would like to thank Jiban Maharjan and his family for providing the land for installing the field experiments. The authors also thank Hermann Mönch, Claudia Bänninger and Karin Rottermann at Eawag for chemical analysis, Loïc Decrey and Brian Sinnet at Eawag for the filter analysis, Subodh Sharma and the team from Kathmandu University for their support, Willem Jan Oosterkamp, and Paul Olivier for the information about using bittern and magnesite for struvite production.

\section{REFERENCES}

Abegglen C.K. (2008) Membrane bioreactor technology for decentralized wastewater treatment and reuse. PhD thesis Nr. 17998, Swiss Federal Institute of Technology Zurich, Switzerland. DOI: 10.3929/ethz-a-005745648

Adetayo A.A., Litster J.D., Desai M. (1993) The effect of process parameters on drum granulation of fertilizers with broad size distributions. Chemical engineering science 48 (23), 3951-3961.

Antonini S., Paris S., Clemens J. (2009) Nitrogen and phosphorus recovery from human urine. In: Arnold U., Gresens F. (ed.) Decentralised Water Treatment Systems in the Mekong Delta. SANSED - PROJECT, Final Report. INRES-Plant Nutrition, University of Bonn, Germany. ISBN 3-937941-14-2.

Bhuiyan, M.I.H., Mavinic, D.S., Koch, F.A. (2008) Phosphorus recovery from wastewater through struvite formation in fluidized bed reactors: a sustainable approach. Water Science and Technology 57 (2), 175-181.

Bhuptawat H., Folkard, G.K., Chaudhari, S. (2007) Innovative physico-chemical treatment of wastewater incorporating Moringa oleifera seed coagulant. Journal of Hazardous Materials 142, 477-482.

Bowers, K.E., Westerman, P.W. (2005) Performance of cone-shaped fluidized bed struvite crystallizers in removing phosphorus from wastewater. Transactions of the American Society of Agricultural Engineers 48 (3), 1227-1234.

Burt, R. ed. (2004) Soil Survey Laboratory Methods Manual. Soil Survey Investigations Report No. 42, Version 4.0. USDA United States Department of Agriculture, USA.

Cheremisinoff, N.P. (1998) Liquid Filtration. Butterworth-Heinemann, Woburn MA, USA. 59-75.

Cordell, D., Drangert J.O., White S. (2009) The Story of Phosphorus: Global food security and food for thought. Journal of Global Environmental Change 19, 292305

DIN 51603-1: Flüssige Brennstoffe - Heizöle - Teil 1: Heizöl EL, Mindestanforderungen. (Liquid fuels - Fuel oils - Part 1: Fuel oils EL, specifications), Deutsches Institut für Normung (DIN, German Institute for Standardization), Version 2008-8, Beuth-Verlag, Berlin, Germany.

El Diwani, G., El Rafie, Sh., El Ibiari, N.N., El Aila, H.I. (2007) Recovery of ammonia nitrogen from industrial wastewater treatment as struvite slow releasing fertilizer. Desalination 214, 200-214.

Etter, B. (2009) Process optimization of low-cost struvite recovery - MSc thesis. EPFL: Swiss Federal Institute of Technology, Lausanne, Switzerland.

Forrest, A.L., Fattah, K.P., Mavinic, D.S., Koch, F.A. (2008) Optimizing struvite production for phosphate recovery in WWTP. Journal of Environmental Engineering 134 (5), 395-402.

Guest S.G., Barnard J.L., Beck M.B., Daigger G.T., Hilger H., Jackson S.J., Karvazy K., Kelly L., MacPherson L., Mihelcic J.R., Pramanik A., Raskin L., van Loosdrecht M.C.M., Yeh D. Love N.G. (2009) A new planning and design paradigm to achieve sustainable resource recovery from wastewater. Environmental Science and Technology 43(16), 6126-6130

Heynemann, J. (2010) personal communication. Fachhochschule Giessen. Supervisor of a struvite reactor at GTZ in Eschborn/Germany.

Johnston, A.E., Richards, I.R. (2004) Effectiveness of Different Precipitated Phosphates as Phosphorus Sources for Plants. Phosphorus Research Bulletin 15 52-59.

Jönsson, H., Richert Stinzing, A., Vinnerås, B., Salomon, E. (2004) Guidelines on the use of urine and faeces in crop production. EcoSanRes Publication Series. Stockholm Environment Institute, Sweden.

Kashekya, E.J. (2009) Struvite production from source separated urine in Nepal: The Reuse Potential of the Effluent. Master's Thesis. Unesco-IHE, Delft, The Netherlands and Swiss Federal Institute of Aquatic Science and Technology (Eawag), Dübendorf, Switzerland.

Katayon, S., Megat Mohd Noor, M.J., Asma, M., Abdul Ghani, L.A., Thamer, A.M., Azni, I., Ahmad, J., Khor, B.C., Suleyman, A.M. (2006) Effects of storage conditions of Moringa oleifera seeds on its performance in coagulation. Bioresource Technology 97, 1455-1460.

Larsen, T.A., Alder, A.C., Eggen, R.I.L., Maurer, M., Lienert, J. (2009) Source separation: Will we see a paradigm shift in wastewater handling? Environmental Science and Technology 43(16), 6121-6125.

Le Corre, K.S., Valsami-Jones, E., Hobbs, P., Jefferson, B., Parsons, S.A. (2007) Agglomeration of struvite crystals. Water Research 41, 419-425.

Lee, S.I., Weon, S.Y., Lee, C.W., Koopman, B. (2003) Removal of nitrogen and phosphate from wastewater by addition of bittern. Chemosphere 51, 265-271.

Liu, Z., Zhao, Q., Lee, D.J., Yang, N. (2008) Enhancing phosphorus recovery by a new internal recycle seeding MAP reactor. Bioresource Technology 99 , 6488-6493. 
Lozano, J.A.F, Colmenares, A.R., Rosas, D. (1999) A novel process for the production of multinutrient phosphatic base fertilizers from seawater bittern and phosphoric acid. Interciencia 24, 317-320.

Maurer, M., Gujer, W. (1995) Monitoring of microbial phosphorus release in batch experiments using electric conductivity. Water Research 29, 2613-2617.

Maurer, M., Pronk, W., Larsen, T.A. (2006) Treatment processes for source-separated urine. Water Research 40 (17), 3151-3166.

Moerman, W., Carballa, M., Vandekerckhove, A., Derycke, D., Verstraete, W. (2009) Phosphate removal in agro-industry: Pilot- and full-scale operationalconsiderations of struvite crystalization. Water Research, doi:10.1016/j. watres.2009.02.007

Niwagaba, C., Nalubega, M., Vinnerås, B., Sundberg, C., Jönsson, H. (2009) Bench-scale composting of source-separated human faeces for sanitation. Waste Management 29 (2), 585-589.

Paris, S., Schlapp, C., Netter, T. (2007) A contribution to sustainable growth by research and development. Proceedings of the International Symposium on ,Water Supply and Sanitation for All', 27-28 Sep 2007. ISBN 13978-1-84339-514-0.

Römer, W. (2006) Plant availability of P from recycling products and phosphate fertilizers in a growth-chamber trial with rye seedlings. Journal of Plant Nutrition and Soil Science 169 (6), 826-832.

Ronteltap, M., Maurer, M., Gujer, W. (2007) The behaviour of pharmaceuticals and heavy metals during struvite precipitation in urine. Water Research 41 , $1859-1868$

Ronteltap, M., Maurer, M., Hausherr, R., Gujer, W. (2010) Struvite precipitation from urine - influencing factors on particle size. Water Research 44, 2038-2046.

Schouw, N.L., Danteravanich, S., Mosbaek, H., Tjell, J.C. (2002) Composition of human excreta - a case study from Southern Thailand. The Science of the Total Environment 286 (1-3), 155-166.

Schuen, R., Parkinson, J., Knapp, A. (2009) Study for Financial and Economic Analysis of Ecological Sanitation in Sub-Saharan Africa. Water and Sanitation Program-Africa, The World Bank, Nairobi, Kenya.

Shand, M.A. (2006) The chemistry and technology of magnesia. John Wiley \& Sons, Hoboken NJ, USA. 83-86.

Smil, V. (2000) Phosphorus in the Environment: Natural Flows and Human Interferences. Annual Review of Energy and the Environment 25, 53-88.

Standard Methods (2006) Standard Methods for the Examination of Water \& Wastewater. APHA American Public Health Association, AWWA American Water Works Association, WEF Water Environment Federation.

Tchobanoglous G., Burton F.L., Stensel H.D. (2004) Metcalf \& Eddy Wastewater Engineering. Treatment and Reuse. 4th ed., McGraw-Hill, Boston.

Tilley, E., Lüthi, C., Morel, A., Zurbrügg, C.,Schertenleib, R. (2008a). Compendium of Sanitation Systems and Technologies. Swiss Federal Institute of Aquatic Science and Technology (Eawag). Dübendorf, Switzerland.

Tilley, E., Atwater, J. and Mavinic, D. (2008b) Recovery of Struvite from stored human urine. Environmental Technology, 29(7), 797-806

Tilley, E., Atwater, J. and Mavinic, D. (2008c) Effects of storage on phosphorus recovery from urine. Environmental Technology, 29(7), 807-816

Tilley, E., Gantenbein, B., Khadka R., Zurbrügg, C., Udert, K.M. (2009) Social and economic feasibility of struvite recovery from urine at the community level in $\mathrm{Ne}$ pal. In: International Conference on Nutrient Recovery from Wastewater Streams. Ashley, K., Mavinic, D., Koch, F. (eds). IWA Publishing, London, 169-178.

Udert, K.M., Larsen, T.A., Biebow, M., Gujer, W. (2003a) Urea hydrolysis and precipitation dynamics in a urine-collecting system. Water Research 37 (11), 2571-2582.

Udert K.M., Larsen T.A., Biebow M., Gujer W. (2003b) Estimating the precipitation potential in urine-collecting systems. Water Research 37 (11), 2667-2677.

Udert K.M., Larsen T.A., Gujer W. (2005) Fate of major compounds in sourceseparated urine. Water Science and Technology 54(11-12), 413-420.

Udert K.M., Wächter M. (2010) Complete nutrient recovery from source-separated urine. Proceedings of the 7th IWA Leading-Edge Conference on Water and Wastewater Technologies, 2-4 June 2010, Phoenix(AZ) USA. Paper in preparation.

UN Habitat (1993) Vertical Shaft Limekiln Technology. United Nations Centre for Human Settlements (Habitat), Nairobi, Kenya. ISBN 92-1-131225-6.

UNIDO (1998) Fertilizer Manual, 3rd ed., United Nations Industrial Development Organization, International Fertilizer Development Center, Kluwer Academic Publishers, Dordrecht.

Venkataraman, V.R. (2010) Personal communication. Chief Executive, Marine Chemicals, The Archean Group of Companies, 5th Floor, Tower 2, Beliciaa Towers, 94 MRC Nagar, 600028 Chennai, India.
WHO/UNICEF (2010) Estimates for the use of Improved Sanitation Facilities: Nepal. Joint Monitoring Programme for Water Supply and Sanitation, Geneva, Switzerland.

Water Aid Nepal and Environmental and Public Health Organization (ENPHO) (2007) Assessment of urine diverting EcoSan toilets in Nepal, Kathmandu, Nepal

Wilsenach, J.A., Schuurbiers, C.A.H., van Loosdrecht, M.C.M. (2007) Phosphate and potassium recovery from source separated urine through struvite precipitation. Water research $41,458-466$.

Wu, J.C. (1994) The mineral industry of Nepal. USGS, Mineral Resources Program, Reston VA, USA.

Wylie, A.C. (2009) Investigation of electrical conductivity as a control parameter for enhanced biological phosphorus removal in a pilot scale sequencing batch reactor. Master thesis. University of British Columbia, Vancouver, Canada. 